\title{
Monitoring of Rainfall Level Ombrometer Observatory (Obs) Type using Android Sharp GP2Y0A41SK0F Sensor
}

\author{
Anton Yudhana ${ }^{1}$, Yunita Dwi Andriliana ${ }^{2}$, Son Ali $\mathrm{Akbar}^{3}$, Sunardi $^{4}$ \\ Dept. of Electrical Engineering, Universitas Ahmad Dahlan \\ Yogyakarta, Indonesia
}

\author{
Subhas Mukhopadhyay ${ }^{5}$ \\ Dept. of Mechanical / Electronic Engineering \\ Macquaire University, NSW, Australia
}

\author{
Ismail Rakip Karas ${ }^{6}$ \\ Dept. of Computer Engineering \\ Karabük University, Karabük, Turkey
}

\begin{abstract}
Measurements of rainfall carried out are generally automatic, but how many parties have carried out research using automatic rain gauge instruments. The rainfall level data obtained can be used to detect flooding so that it reduces the occurrence of natural disasters earlier. The principle works are when rain falls the water is collected and the height will be detected. The Sharp GP2Y0A41SK0F sensor will be read on Arduino Uno and pass through the signal conditioning circuit and then forwarded to the Water Pump to pump water so that the water comes out of the tube and the data will be stored. ESP8266, the Wi-Fi module will send data to Android. Measurements are made when the water is full the value of max 53.2 means heavy rain. After the data is obtained, then look for the standard error of the measurement tool for 7 days. The design of the model builds a tool using a funnel with a diameter of $14 \mathrm{~cm}$ and a height of $26 \mathrm{~cm}$. Based on the calculation of the design that has been made the measuring instrument developed is able to measure rainfall up to $26000 \mathrm{~mm}$ rain height.
\end{abstract}

Keywords-Arduino; infrared sensor; android; observatory; rainfall

\section{INTRODUCTION}

Rain in Indonesia has an average rainfall as an illustration of normal rainfall conditions using historical gsmap data [1]. The resources used to calculate rainfall are rain gauge, landbased radar, and remote sensing satellites. The purpose of this study is to spread the aerial photography system that has the ability to capture panoramic images of certain areas. The season that occurs in Indonesia is based on the frequent or infrequent rainfall so that it is known as the rainy season and the dry season [2], [3]. The type of rain in the Central Java region is monsoonal, a characteristic pattern of monsoon types of rainfall that is unimodal (peak rainy season) [4]. For example, $1 \mathrm{~mm}$ of rainfall means that rainwater has a height of $1 \mathrm{~mm}$ which is accommodated in a flat place with an area of 1 $\mathrm{m}^{2}[5]$.

An ordinary manual rain gauge used in Indonesia is a type an ordinary manual rain gauge used in Indonesia is a type Observatorium or Ombrometer. Manual rain gauge (Manual Rain Gauge) consists of two types, viz. MRG with a surface area of $100 \mathrm{~cm} 2$ and $200 \mathrm{~cm} 2$ [6]. We have reported an effective implementation for the Internet of Things used for monitoring regular domestic conditions by means of low-cost ubiquitous sensing system [7]. In the android step monitoring application to connect to the hardware is connected with Bluetooth HC-06. After being able to connect with Bluetooth, the monitoring results the measurement value will be displayed on Android [8].

The working principle of the Sharp GP2Y0A41SK0F sensor is that the sensor will emit infrared light with a frequency of $40 \mathrm{kHz}$ and the reflection of the sensor will be received by the infrared detector array [9]. Android (operating system) is an operating system based on Linux for cellular phones such as smartphones and tablet computers[10]. use rain sensors for water detection and light sensors for sunny or cloudy weather detectors that will send input to Arduino uno to provide buzzer output, and short message service (SMS) notifications to turn on relays to control DC motors to open and close the roof [11]. The results of the design performance of the tool can monitor the height of rainfall which is then analyzed in the form of a database and can store data 24 hours automatically to be used as a historical and graphical data [12], [13].

The results of the characterization of the sensor that shows the flow of water with the effect of the hall with the response in the form of voltage, but the characterization of response time and stability is still less responsive and less sensitive. IC chip that has the function of calculating the time starting from seconds, minutes, hours, days, dates, months, to years accurately [14]. All devices measuring the water level can work well according to the sensors used. The results of testing the data displayed on this gauge are as expected [15]. All devices measuring the water level can work well according to the sensors used. The results of testing the data displayed on this gauge are as expected [16], [17]. Use of ESP8266 Module as a WIFI module, widely used by Internet-based applications of Things because the price is cheap, thus reducing many costs and have a pretty good speed of $80 \mathrm{MHz}$ [18]. 


\section{RESEARCH METHOD}

In this research, the method explained the results of the study and simultaneously provided an in-depth discussion. Results can be displayed with Images and others that make the reader easy to understand. Discussion can be made in several.

\section{A. System Planning}

To realize the design of rainfall measuring devices carried out in several steps to find out the stages of making the tool to completion. This flow chart shows the making of the tool consists of two stages, namely the stage of making the hardware and software design stage. To start the Arduino program (for making the program will be in accordance with what we want) we use Arduino IDE (Integrated Development Environment) [19].

In making this tool, two stages consisting of hardware and software that is in order to produce the appropriate measuring instrument. After learning and understanding the work system of the tools to be made, then make a system design by making hardware or hardware from the tool. Then testing the resulting hardware can work well or not. The hardware has been realized and is functioning properly, then making software design. The design of this software will help use hardware (hardware). If both of them have succeeded and are functioning properly, then the whole tool is tested.

Based on Fig. 1, flow chart of the system design of rainfall level detection above explains the workings of the rainfall level monitoring system. When Sharp GP2Y0A41SK0F does not detect the water level, the relay will be active at 07:00 in the morning and do the handling and sending of data on ThinkSpeak. If the water is full with a height greater than $5 \mathrm{~cm}$ while at less than 07:00 then it will make arrangements and sending data on ThinkSpeak. The graphic display on ThinkSpeak will run according to data obtained from the sensor.

\section{B. Hardware Designing}

The hardware in this Android-based rainfall level monitoring tool consists of a control system and data acquisition. The control system scheme in the tool is shown in the following Fig. 2, block diagram.

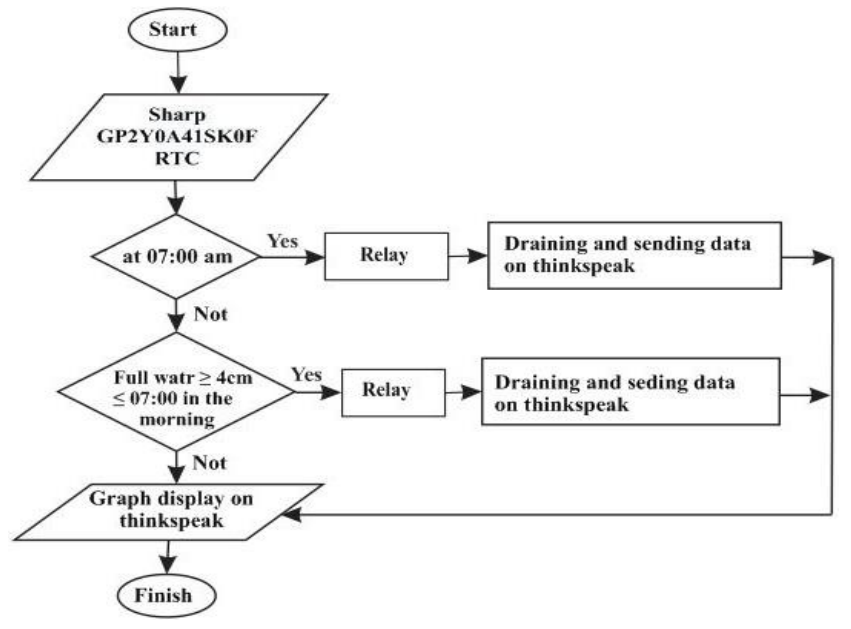

Fig. 1. System Design Flowchart.

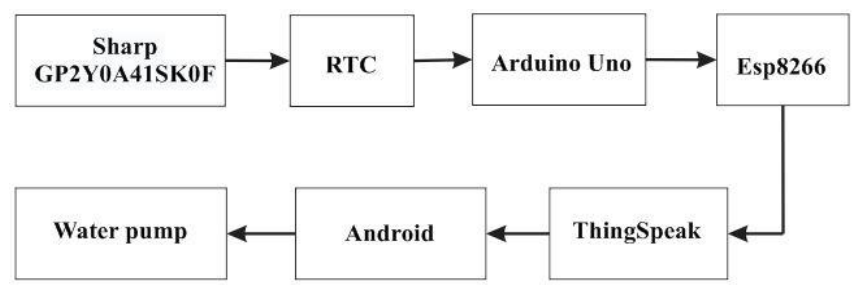

Fig. 2. Block System Design Diagram.

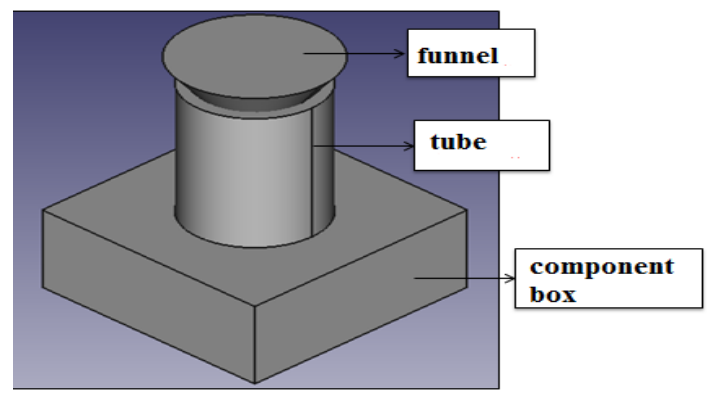

Fig. 3. Design Results of Monitoring Android-based Rainfall Levels.

The following is Fig. 3, the results of the design model of the rainfall level detection tool based on Arduino Uno.

Based on Fig. 3, the design of the data system from the design of an Android-based rainfall level monitoring tool explains that the volume of collected rainwater will provide measurable value by utilizing the Infrared Sensor. The output of the Infrared sensor will be read by Arduino Uno after passing the Arduino signal conditioning circuit. The analog value produced by the sensor will be read by Arduino and forwarded to the Water Pump to pump water so that the water comes out of the tube and the data will be stored, then ESP8266 The Wi-Fi module will send data to Android.

\section{Algoritma}

Calculating altitude using equations that are already widely known [20]. To calculate the height of rainwater that falls in a field with a certain area you can use the equation:

$H=\frac{V}{L}$

$\mathrm{H}=$ height of rainfall

$\mathrm{V}=$ Volume

$\mathrm{L}=$ area

A funnel with a diameter of $14 \mathrm{~cm}$ is used in measuring rainfall, meaning that the area of the funnel can be calculated by the equation:

Count the funnel radius as follows:

$R=\frac{\text { (Funnel diameter) }}{2}$

Area calculation as follows:

$\mathrm{L}=\pi \times \mathrm{R}^{2}$

Known :

$\pi=3.14$ 
$\mathrm{R}=$ funnel radius

Volume calculation is as follows:

$\mathrm{V}=\mathrm{L} \times$ tube height

Known :

$\mathrm{V}=$ Volume

$\mathrm{L}=$ Field area

Calculates the standard deviation as follows:

Standard Error $=$ Accurate Data-Measured Data $=$ $\frac{X}{\text { Accurate Data }}$

Known :

$\mathrm{N}=4$

Measured Data $=53.2 \mathrm{~mm}$

Accurate Data $=76.50$

\section{RESULTS AND DISCUSSION}

The results and discussion of the design that has been made can be described in the following steps.

\section{A. Infrared Sensor Testing}

Infrared sensor testing is done by distance testing using a ruler as a measuring medium, the match between the distance from the meter and the results displayed on the web and android. Fig. 4, the results obtained show the water level used in sensor testing.

\section{B. Hardware Testing}

The circuit in Fig. 5 will turn on the relay and the pump will automatically turn on and suck the water inside the tube. Data transmission will be carried out when the relay and pump are on. Data will be sent to the database and android in the form of a graph. The graph will run smoothly if the internet connection used has a good network. This circuit uses a 12-volt voltage generated from the adapter.

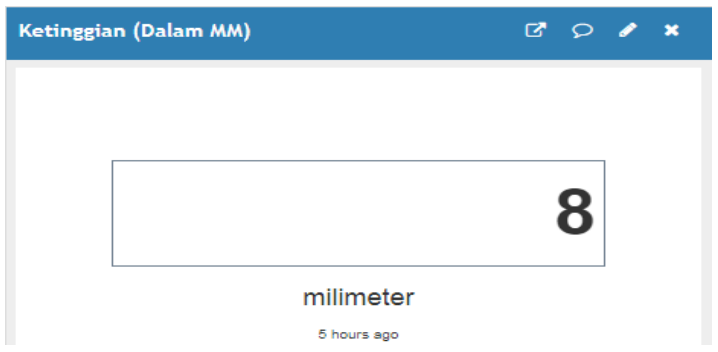

Fig. 4. Infrared Sensors.

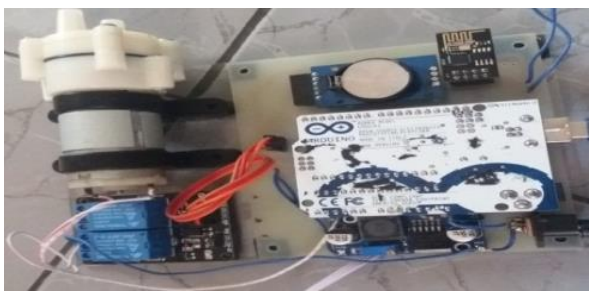

Fig. 5. Hardware Testing.

\section{Software Testing}

In testing Fig. 6, programs written in the Arduino IDE software will be checked for program listings whether or not the program has errors that can interfere with the performance of the system. This test is done by combining sensor listings with other component listings.

\section{Testing of Rainfall Measurement Tools}

The testing of rainfall testing equipment is carried out in the event of rain or heavy rain. This measurement is done by measuring the height of water entering the tube will be measured automatically with the sensor.

Calculate funnel radius using equation (2) as follows:

$R=\frac{14}{2}=7$

Measurement of rainfall using a funnel, used a funnel with a diameter of $14 \mathrm{~cm}$ and a height of $26 \mathrm{~cm}$. The area calculation below uses equation (3):

$L=3,14 \times 7 \times 7=153,86$

Calculate volume using equation (4):

$\mathrm{V}=153,86 \times 26=4.000,36$

Calculate the height of rain using equation (1):

Rainfall height $(H)=\frac{4.000,36}{153,86}=26000 \mathrm{~mm}$

Table I is a table that will contain the results obtained during the measurements that have been made. After doing the calculation, the average value of the calculation will be used.

The results obtained in Table I show that the average rainfall obtained in this measurement is low. Data were taken every time it rains only 1 data and data used is data that approaches the value of manual calculation. After the measurement has been completed calculation. Table II is a table of manual calculations on the BMKG tool. In Table I and Table II, a comparison is made to determine the standard error of the measuring instrument.

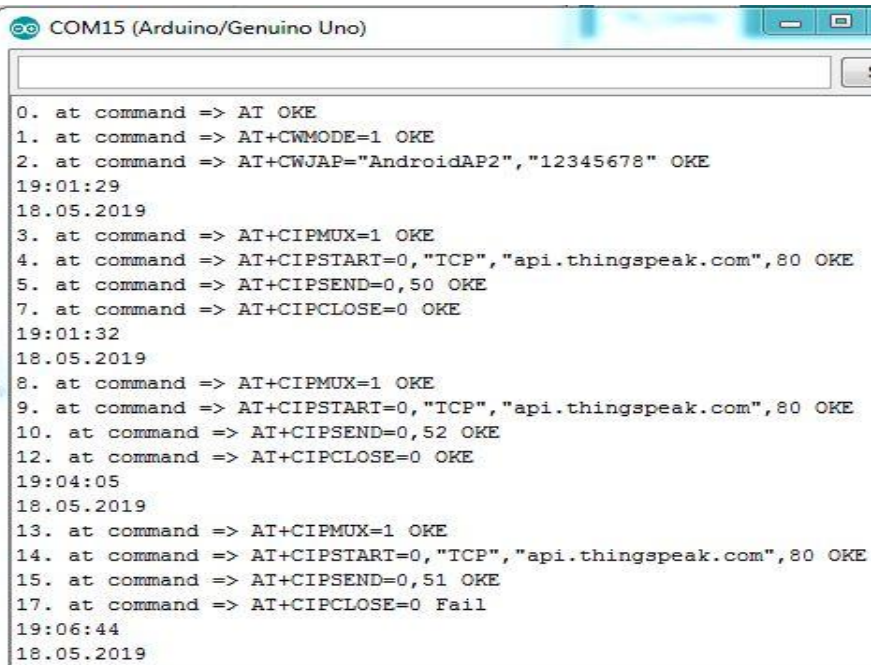


TABLE. I. RAINFALL MEASUREMENT

\begin{tabular}{|l|l|l|l|l|}
\hline No. & Date/Time & $\begin{array}{l}\text { Time } \\
(\text { WIB })\end{array}$ & $\begin{array}{l}\text { Water } \\
\text { Level } \\
(\mathbf{m m})\end{array}$ & Explanation \\
\hline 1. & Wednesday, 15 May 2019 & $03: 32$ & 17,0 & Low \\
\hline 2. & Friday, 17 May 2019 & $23: 35$ & 53,2 & High \\
\hline 3. & Saturday, 18 May 2019 & $08: 31$ & 38,0 & Low \\
\hline 4. & Wednesday, 22 May 2019 & $10: 22$ & 0 & Low \\
\hline 5. & Thursday, 23 May 2019 & $14: 10$ & 5,4 & Low \\
\cline { 1 - 2 }. & Friday, 24 May 2019 & $16: 07$ & 0 & Low \\
\hline 7. & Saturday, 25 May 2019 & $05: 48$ & 0 & Low \\
\cline { 1 - 2 }$n=7$ & & 261,7 & \\
\cline { 1 - 2 } Average & 38,3 & \\
\hline
\end{tabular}

The manual measurement carried out by BMKG in Table II has a description of low rainfall so that it does not cause flooding in an area. The importance of BMKG manual measurement is done as a comparison of measurements on the measurement tools of the current research so that researchers can find out how much error occurred in the research measuring instrument.

After the data obtained by the measurement data will then look for the standard deviation of the rainfall gauge for 7 days, the standard deviation formula is obtained using equation (5):

Standard Error $=76,50 \mathrm{~mm}-53,2 \mathrm{~mm}=\frac{23,3 \mathrm{~mm}}{76,50 \mathrm{~mm}}=0,30$

$0,30 \times 100 \%=30 \%$

TABLE. II. MANUAL BMKG MEASUREMENT OF RAINFALL

\begin{tabular}{|l|l|l|l|l|}
\hline No. & Date/Time & $\begin{array}{l}\text { Time } \\
\text { (WIB) }\end{array}$ & $\begin{array}{l}\text { Water } \\
\text { Level } \\
(\mathbf{m m})\end{array}$ & Explanation \\
\hline 1. & Wednesday, 15 May 2019 & $03: 32$ & 17,0 & Low \\
\hline 2. & Friday, 17 May 2019 & $23: 35$ & 76,50 & High \\
\hline 3. & Saturday, 18 May 2019 & $08: 31$ & 46,2 & Low \\
\hline 4. & Wednesday, 22 May 2019 & $10: 22$ & 0 & Low \\
\hline 5. & Thursday, 23 May 2019 & $14: 10$ & 6,4 & Low \\
\hline 6. & Friday, 24 May 2019 & $16: 07$ & 0 & Low \\
\cline { 1 - 2 } 7. & Saturday, 25 May 2019 & $05: 48$ & 0 & Low \\
\cline { 1 - 2 } $\mathrm{n}=7$ & & 103,1 & \\
\cline { 1 - 1 } Average & 14,73 & \\
\hline
\end{tabular}

TABLE. III. STANDARDS OF RAINFALL DEVIATION

\begin{tabular}{|l|l|l|l|}
\hline No. & Date/Time & Error & Percentage \\
\hline 1. & Wednesday, 15 May 2019 & 0 & 0 \\
\hline 2. & Friday, 17 May 2019 & 0,30 & $30 \%$ \\
\hline 3. & Saturday, 18 May 2019 & 0,18 & $18 \%$ \\
\hline 4. & Wednesday, 22 May 2019 & 0 & $0 \%$ \\
\hline 5. & Thursday, 23 May 2019 & 0,16 & $16 \%$ \\
\hline 6. & Friday, 24 May 2019 & 0 & $0 \%$ \\
\hline 7. & Saturday, 25 May 2019 & 0 & $0 \%$ \\
\hline
\end{tabular}

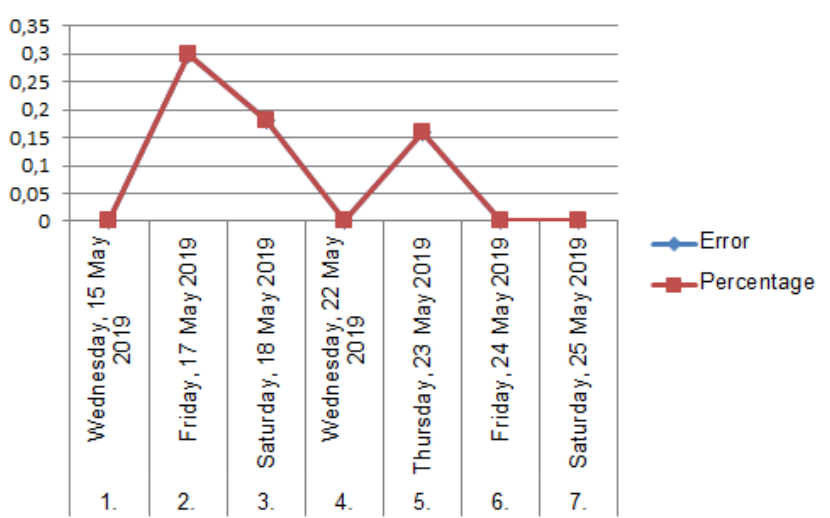

Fig. 7. Graphic Standard Deviation of Rainfall.

After calculating the standard deviation in Table III using equation (2), the result of the error value is $30 \%$.

The results of error Table III were carried out from a comparison of current research and the BMKG manual measurements obtained were quite large. So we can find out what capacity can be measured from this research tool. Fig. 7 shows a graph of the comparison of research tools and BMKG tools.

\section{E. Testing the Application on an Android Phone}

Android testing in Fig. 8 uses the Thingview application. This test is carried out to monitor the level of rainfall at home using Android. The following is a view of Thingview that can display data sent by Thingspeak.

Data transmission from Thingspeak to Thingview obtained in Fig. 8 is a test performed on android and performs the process of sending data 26 times. Data transmission that is the process of sending it via Android results obtained is the same as the process of sending it through the website. Data transmission on Android is done every 3 minutes so that the water in the tube does not occur evaporation. This remote monitoring is very easy for us to monitor rain that occurs in an area without the need to manually check the measuring instrument.

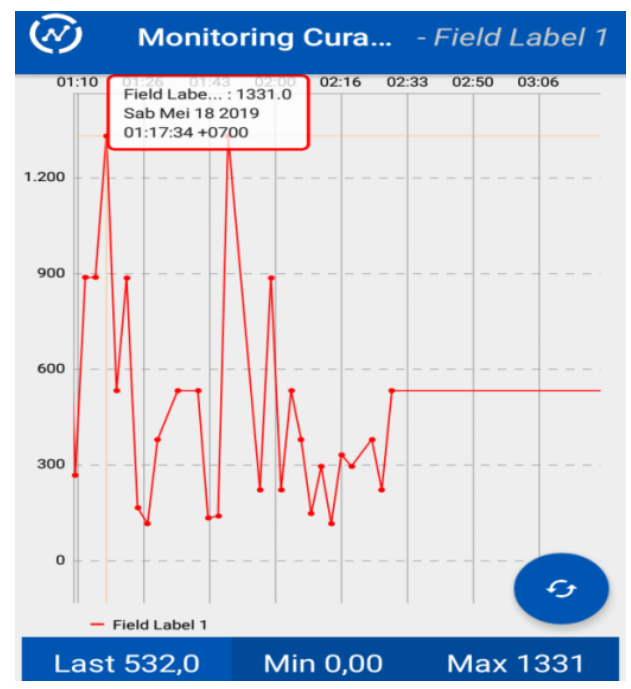

Fig. 8. Testing Android. 


\section{CONCLUSION}

The design of the tool building model in this study uses a funnel with a diameter of $14 \mathrm{~cm}$ and a height of $26 \mathrm{~cm}$. Based on the design calculations that have been made measuring devices are designed to be able to measure rainfall up to a height of $26000 \mathrm{~mm}$. The research that has been done can measure the rainfall in the measuring tube using the Sharp GP2Y0A41SK0F sensor which has been working in accordance with its functions and uses. The minimum sensor distance sensor measurement is $4 \mathrm{~cm}$. The results obtained from the sensor readings will be received on the website and can be accessed via Android. All levels of rainfall monitoring based on Android can be used properly and can be used such as the use and function of sensors that have been used. Test tool in 7 days to get accurate data about the process of sending data stored on the website and the process of sending data can be received via Android. Data obtained from participation in rainfall calculation has an error of 30\%. The development of tools that should be done in the future is to compare research tools with BMKG tools directly.

\section{ACKNOWLEDGMENT}

Acknowledgments are given by LPPM UAD for providing PKLN 2019 research funds with contract numbers PKLN-PI001/SP3/LPPM-UAD/IV/2019.

\section{REFERENCES}

[1] Athoillah, R. M. Sibarani, and D. E. Doloksaribu, "Analisis Spasial El Nino Kuat Tahun 2015 Dan La Nina Lemah Tahun 2016 ( Pengaruhnya Terhadap Kelembapan, Angin dan Curah Hujan di Indonesia )," J. Sains Teknol. Modif. Cuaca, vol. 18, no. 1, pp. 33-41, 2017.

[2] D. R. Prabawadhani, B. Harsoyo, T. H. Seto, and M. B. R. Prayoga, "Karakteristik Temporal Dan Spasial Curah Hujan Penyebab Banjir Di Wilayah Dki Jakarta Dan Sekitarnya," J. Sains Teknol. Modif. Cuaca, vol. 17, no. 1, pp. 21-25, 2016.

[3] A. Yudhana, N. S. Widodo, and Sunardi, "Implementation of Quadcopter for Capturing Panoramic Image at Sedayu Bantul," Proceeding 1st Int. Conf. Comput. Sci. Eng., pp. 37-39, 2014.

[4] Misnawati, R. Boer, T. June, and A. Faqih, "Perbandingan metodologi koreksi bias data curah hujan chirps," LIMNOTEK Perair. Darat Trop. di Indones., vol. 25, no. 1, pp. 18-29, 2018.

[5] D. Mulyono, J. Konstruksi, S. Tinggi, T. Garut, and C. Hujan, "Analisis karakteristik curah hujan di wilayah kabupaten garut selatan," J. Konstr., vol. 13, pp. 1-9, 2014.
[6] A. Petonengan, J. S. F. Sumarauw, and E. M. Wuisan, "Pola distribusi hujan jam-jaman di das tondano bagian hulu," J. Sipil Statik Vol.4, vol. 4, no. 1, pp. 21-28, 2016.

[7] S. D. T. Kelly, N. K. Suryadevara, and S. C. Mukhopadhyay, "Towards the Implementation of IoT for Environmental Condition Monitoring in Homes," IEEE Sens. J., no. c, 2013.

[8] A. Yudhana and A. C. Kusuma, "Water quality monitoring at paddies farming based on android," IOP Conf. Ser. Mater. Sci. Eng., 2018.

[9] A. B. Vernandez, M. Facta, and T. Sukmadi, "Perancangan Konverter DC-DC Topologi Buck Berbasis Mikrokontroller Atmega8535 Untuk Aplikasi Heater Ekstraksi Biji Kapuk," 2015.

[10] D. W. E. Sede, A. A. E. Sinsuw, and X. B. N. Najoan, "Rancang Bangun Aplikasi Pemesanan Tiket Online Kapal Laut Berbasis Android," vol. 1, no. 1, 2015.

[11] A. A. Handaru et al., "Menggunakan Modul GSM Berbasis Mikrokontroler," Sci. Electro, pp. 25-30, 2019.

[12] M. A. Novianta, "Sistem Data Logger Curah Hujan Dengan Model Tipping Bucket Berbasis Mikrokontroller," J. Teknol., vol. 4, no. 28, 2011.

[13] R. G. Permana, E. Rahmawati, and Dzulkiflih, "Perancangan Dan Pengujian Penakar Hujan Tipe Tipping Bucket Dengan Sensor Photo Interrupter Berbasis Arduino,” J. Inov. Fis. Indones., vol. 04, pp. 77-76, 2015.

[14] M. J. D. Suryanto and T. Rijanto, "Rancang Bangun Alat Pencatat Biaya Pemakaian Energi Listrik Pada Kamar Kos Menggunakan Modul Global System For Mobile Communications(Gsm) 8001 Berbasis Arduino Uno," J. Tek. ELEKTRO, vol. 8, pp. 47-55, 2019.

[15] S. Hidayat and Mushlihudin, "Alat Ukur Tinggi Muka Air Berbasis," J. Ilmu Tek. Elektro Komput. dan Inform., vol. 3, no. 2, pp. 96-100, 2017.

[16] A. Yudhana, Sunardi, and A. Ikrom, "Aplikasi Android Untuk Monitoring Kualitas Lahan Pertanian,” Pros. SNST Fak. Tek., pp. 7-12, 2018.

[17] A. Yudhana and M. D. D. Putra, "Rancang Bangun Sistem Pemantauan Infus Berbasis Android," Transmisi, vol. 20, no. 2, pp. 91-95, 2018.

[18] U. Syafiqoh and A. Yudhana, "Pengembangan Wireless Sensor Network Berbasis Internet of Things untuk Sistem Pemantauan Kualitas Air dan Tanah Pertanian,” J. Pengemb. IT, no. 02, pp. 285-289, 2018.

[19] A. Adriansyah and O. Hidyatama, "Rancang Bangun Prototipe Elevator Menggunakan Microcontroller Arduino Atmega 328p," J. Teknol. Elektro, Univ. Mercu, vol. 4, no. 3, pp. 100-112, 2013.

[20] BMKG, "Mengenal Alat Ukur Cuaca dan Penakar Hujan Sederhana Serta Kalibrasinya," BADAN Meteorol. Klimatologi DAN Geofis. Stasiun Klimatologi Mlati, 2015. 